\title{
GENERAL INTRODUCTION: MARINE SCIENCE ESSAYS
}

\author{
JAMES E. STEWART \\ Ecosystem Research Division, Science Branch \\ Department of Fisheries and Oceans, Maritimes Region \\ Bedford Institute of Oceanography \\ PO Box 1006 \\ Dartmouth, Nova Scotia B2Y 4A2
}

In 2012, the Bedford Institute of Oceanography will celebrate its 50th anniversary. Such a landmark is an appropriate time for the Institute to take stock, consider its past and debate the course or courses that should be pursued in the future. To aid such an examination it was decided that a written symposium, in which a number of key fields in Marine Science were described and analysed, would give a clear picture of the fundamentals of these fields and demonstrate why they should be of concern and interest to the average person as well as to the scientists involved.

These thoughts are now presented in this published set of 5 articles prepared by distinguished senior scientists currently associated with the Bedford Institute in full time or emeritus positions. Apart from the General Introduction the articles cover the fields of:

1) Marine Geology

2) Physical Oceanography

3) Biological Oceanography

4) Fisheries Science

5) Marine Ecosystems Assessment

In these several articles the authors provide information on historical and background events and attempt to answer such questions as:

1) What is involved in acquiring the relevant information?

2) What can be done with the information?

3) Where are these various fields headed (nationally and internationally) and where in the writers' opinions should they be headed?

4) What benefits can be derived by following the courses advocated and what penalties accrue by not following them?

A useful beginning can be made, by illustrating the importance of marine areas to Canada and the scale of marine sciences needed, through a summary description of the marine areas associated with the Canadian land mass. This land mass totals 9.97 million square kilometres $\left(\mathrm{km}^{2}\right)$ fronting on 3 quite diverse oceans, the Pacific, Arctic and Atlantic. In accordance with 
the 1982 United Nations (UN) Convention on the Law of the Sea (LOSC) Canada's jurisdiction over its adjacent marine areas consists of the 200 nautical mile $(\mathrm{nm})$ Exclusive Economic Zone (EEZ) that includes a $12 \mathrm{~nm}$ territorial sea and a $24 \mathrm{~nm}$ contiguous zone for a total of 4.62 million $\mathrm{km}^{2}$. In addition, Article 76 of the LOSC provides for defining and claiming "extensions to offshore areas beyond $200 \mathrm{~nm}$ where coastal nations with wide continental margins may exercise sovereign rights over mineral and certain biological resources, and also wield a measure of jurisdiction in matters related to environment and conservation. With wide continental margins on its eastern and northern coasts Canada has an opportunity under the terms of the Convention to support national jurisdiction and authority beyond the $200 \mathrm{~nm}$ limits in the Atlantic and Arctic Oceans. The total area potentially could equal that of Canada's three prairie provinces" (Macnab 1994).

Provisional calculations based upon existing information suggest that the total size of the area beyond the $200 \mathrm{~nm}$ limit claimable by Canada could add another 1.76 million $\mathrm{km}^{2}$ to the offshore areas. The 4.62 million $\mathrm{km}^{2}$ within the EEZ plus the possible claimable 1.76 million $\mathrm{km}^{2}$ outside the $200 \mathrm{~nm}$ limit totals 6.38 million $\mathrm{km}^{2}$, an area equal to $64 \%$ of the 9.97 million $\mathrm{km}^{2}$ Canadian land mass (see Fig 1). Claims for all

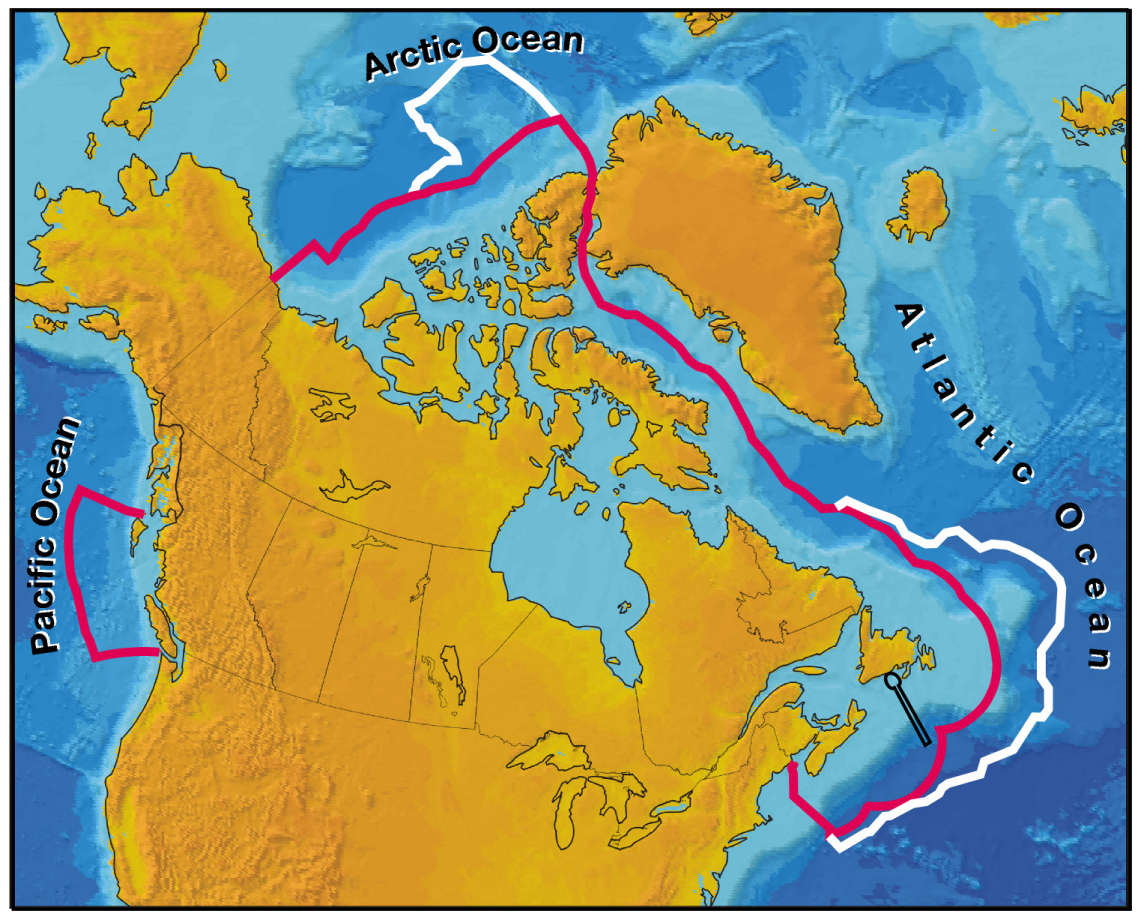

Fig 1 Map of Canada illustrating the 200 nautical mile limit outlined in red (i.e. the Exclusive Economic Zone) and the potentially claimable areas outlined in white. The French Zone south of Newfoundland is rendered in black (redrawn from Macnab 1994). 
of the areas outside the $200 \mathrm{~nm}$ limit, of course, must be supported by specific, accurate and highly detailed data assembled, analysed and submitted within 10 years of the date notification of a claim is filed. All of these possible claimable marine areas encompass regions that have considerable potential for minerals including gas, oil, and gas hydrates; exploitable fisheries, however, are confined with numerous restrictions to bottom dwelling species. The overriding need will be to explore, evaluate and assess the potential.

In addition to the physical and biological attributes of the total marine areas, it will be necessary to determine how the systems interact and relate to Canadians' every day life through exercising marked influences over weather and climate which in turn govern agriculture, fisheries, mineral extractions etc. Canada's approach regarding this enormous marine area is best discerned in the preamble to Bill C-26, an Act respecting the Oceans of Canada promulgated in 1997. This Oceans Act laid the foundation for an integrated and balanced national oceans policy framework supported by regional management and implementation strategies. The Preamble to the Oceans Act has been summarized as follows (Herbert 1999):

- Canada promotes the understanding of ocean processes, marine resources and marine ecosystems to foster sustainable development of the oceans.

- Canada holds that conservation, based on an ecosystem approach is of fundamental importance to maintaining biological diversity and productivity in the marine environment.

- Canada promotes the wide application of the precautionary approach to the conservation, management and exploitation of marine resources in order to protect these resources and preserve the marine environment.

- Canada promotes the integrated management of oceans and their resources.

- Under the Oceans Act the lead role is given to the Department of Fisheries and Oceans (DFO) and directs "The Minister (of DFO) in collaboration with other ministers, boards and agencies of the Government of Canada, with provincial and territorial governments and with affected aboriginal organizations, coastal communities and other persons and bodies .......... Shall lead and facilitate the development and implementation of a national strategy for the management of estuarine, coastal and marine ecosystems".

Thus the National Oceans Strategy as directed by the Oceans Act is based on the principles of sustainable development, integrated management, and the precautionary approach to decision making.

As part of the development of a comprehensive strategy for integrated ocean management intended to serve during the 21st century, the following issue areas have been identified (Herbert 1999): 
- Understanding Our Oceans

- Conserving Oceans Biodiversity

- Marine Environmental Quality

- Shipping and Maritime Safety

- Integrated Planning and Management

- Ocean Industries and Related Opportunities

- Aboriginal Issues

- Arctic Issues

- Maritime Safety and Enforcement

- International Considerations

- Public and Community Awareness and Participation

To provide the databases upon which such a strategy can be developed will require immense efforts by the many people participating in the multiple disciplines and agencies involved with marine affairs. Although no one body, agency or discipline will be able to provide everything that is required, each group bearing significant or particular responsibilities, must know its role and how it relates to the whole. In addition, it is obvious that only through the best efforts of private ventures, academic institutions and governmental agencies working in combination will the requisite information bases be made available to adequately underpin a comprehensive strategy. In this set of essays, we have attempted to examine in some depth the history and accomplishments in several areas relevant to the overall requirements that are or can be conducted by facilities such as the Bedford Institute of Oceanography and its associated laboratory, the St Andrews Biological Station, that are mandated to investigate important areas in the marine sciences. In addition to their strengths as institutes engaged in in-depth scientific studies, as parts of a government agency they also bring specific, unique built-in capacities and responsibilities i.e.:

- Relatively rapid responses to emergencies

- Continuity

- Archiving

- Responsibilities for specified official international interactions and collaborations

Although part of the impetus for this written symposium is to provide sound documentation for discussions concerning programming at $\mathrm{BIO}$ and St Andrews specifically, the debate will immediately and inevitably draw in and upon studies at other institutions locally and abroad. Not only should the discussions and debates range widely, but also they should recognize an underlying urgency. In this regard, it is impossible to function in the marine sciences these days without being made aware, almost on a daily basis, of the threats, from many sources, to the well being of the marine and freshwater ecosystems and environments. 
One of the most comprehensive and balanced reports available on this topic is the 522-page report prepared in 2004 by the United States Commission on Ocean Policy entitled "An Ocean Blueprint for the 21st Century". In examining the total benefits which accrue to the US from the entire ocean, coasts and Great Lakes, the Commission concluded "the contribution swells to over $\$ 4.5$ trillion, fully half the nation's gross domestic product ........." The report goes on to state that "Unfortunately, our use and enjoyment of the ocean and its resources have come with costs, and we are only now discovering the full extent of the consequences of our actions." In its earlier preliminary report, the commission stated that it had found "among other things, depleted resources, over-exploitation of many fish stocks, lost habitat, decreased resiliency of ocean and coastal ecosystems and pervasive water contamination problems". The Commission chairman went on to state, "Fundamentally, the message we heard boiled down to this: the oceans and coasts are in trouble and we need to change the way we manage them. Perhaps most important, people must grasp the vital role oceans play in their lives and livelihoods and the profound impact they, themselves, have on the oceans and coasts. What's now obvious is that ocean resources are not limitless. Nor are ocean waters capable of continual self-cleansing. We can create an improved policy that balances use with sustainability, is based on sound science and educational excellence .........." The report puts forward over 200 recommendations affecting items ranging from upstream areas to the depths of the sea, from practical problem solving to broad guidance for ocean policy. The report, although concerned with ocean matters directly connected to US interests, has a high degree of relevance and commonality for all coastal states. The urgency expressed in the report and many of the approaches advocated also are of immediate importance to all coastal states.

\section{THE ESSAYS ON MARINE SCIENCES}

\section{Marine Geology}

This essay is presented first as the decision was made arbitrarily to begin with the more physical approaches moving through to the more biological. The authors, as would be expected, begin with an historical account and then move rapidly to cataloguing the issues past and present, and complete their account with an in-depth consideration of the coming decade.

As they emphasize, understanding the geological framework and geological processes is necessary for safe and sustainable management of seabed resources. Although ravages of beach mining largely have been halted, the number of people in the coastal zone continues to grow resulting in more causeways, bridges, docks, marinas and shoreline protection structures which affect the stability of the coastline. They point out that not only is there a need to predict the consequences of storms, but also the impacts of the continuing rise of the sea itself, both exacerbated by global warming. 
The two priorities they foresee for government marine geoscience are: 1) sea bed mapping for ocean management, including safe and sustainable use of natural resources; and 2) societal responses in the coastal zone to natural hazards, global climate change and anthropogenic pressures including environmental degradation. In addition, much of the burden for exploring and preparing inventories in the areas claimed beyond the 200 $\mathrm{nm}$ limit will be placed on the geosciences.

Delivering these programs will require a strong, integrated Canadian science program (involving universities, industry and government) in the history of glaciation, sediment transport, numerical modelling especially of coastal zone changes, estuarine studies and increasingly multidisciplinary approaches. New tools will be required; research vessels, greatly increased remote sensing, autonomous underwater vehicles, improved high resolution seismic equipment and seafloor camera systems, and improved methods to deal with the rapidly accumulating masses of data. In addition, an oftenoverlooked element will be the need to maintain and strengthen links with the international marine geoscience community in order to fill numerous gaps in the Canadian marine geoscience program.

\section{Physical Oceanography}

It is generally agreed that the beginning of this field as a science dates from the ChallengerExpedition of 1872-1876. As noted in this essay, Halifax was the first port of call for the Challenger after it had occupied a series of oceanographic stations across the North Atlantic in the crossing from England. Early oceanographic expeditions yielded a broad description of the physical, chemical and biological distributions in the oceans, but were not able to delineate the processes that governed those distributions. The development of the theoretical basis for the dynamics of the oceans and the atmosphere was pioneered at the beginning of the 20th century by Scandinavian oceanographers and meteorologists.

In fact, it was the leading Norwegian marine scientist, Johan Hjort, who supervised the first systematic physical oceanographic survey in Atlantic Canada. Dr. Hjort, on the basis of his studies in Norway, was invited by the Canadian Government to lead the 1914-1915 Canadian Fisheries Expedition. The results of this demonstration expedition were so impressive that throughout the 1920s and '30s this work was continued in Atlantic Canada especially by the staff of the St. Andrews Biological Station.

Physical oceanography, over its first century plus, has developed the theoretical understanding as well as the observational, analytical and modelling tools to design and operate ocean observing systems that can deliver reliable information from the open ocean, shelf seas and inshore environments. Beginning as a science devoted largely to supply information to navigators and improve safety at sea, it has become a sophisticated endeavour that can stand alone in resolving important questions. These questions range from the role of the oceans as major determinants of climate and weather to the flow of nutrients within the oceanic bodies which 
determine to a large extent the variations in the productivity of large areas of the ocean e.g. the immense anchovy fishery off Peru governed by such elements as the EI Niño Southern Oscillation.

This essay also offers the opportunity to consider the comments made by Sverdrup (1955) who stated that, "physical oceanography is in the unique position of being independent of the other marine sciences while serving as an auxiliary science to these".

As described herein, physical oceanography is an applied science upon which many other scientific enterprises depend. Although the need for cooperation with other branches of science was recognized from the outset, it unfortunately has not always happened. In discussing this topic Sverdrup pleads that, "the necessity of cooperation between marine scientists cannot be expressed too often". He attributes the failure to achieve this essential level of cooperation to a lack of breadth in training for all sciences and particularly between physical oceanographers and marine biologists, "perhaps because they have difficulty in talking in terms which are mutually understood". To a considerable extent the overall thrust in the various essays illustrates the degree to which the admonitions of leading scientists such as Sverdrup and Bigelow (cited by Sverdrup 1955) have been taken to heart and applied.

\section{Biological Oceanography}

It is clear from the contents of this essay that the advice offered by Sverdrup (1955) on the need of marine scientists to broaden their training so as to enhance mutual understanding has been heard and applied. Attention is drawn to the broad range of biological oceanography by citing a course description that includes the topics of marine microbial ecology, phytoplankton ecology and marine primary productivity, zooplankton ecology, benthic ecology etc. The case is made that the field is extremely diversified and consists of such an amalgam of transformations of chemical components mediated by biological systems that the far broader term "biogeochemistry" might be a more appropriate descriptor than "biological oceanography".

Biological oceanography has been reviewed comprehensively and an analysis is given of the progress made in Canada since a major review by Parsons (1975). Although multi-disciplinary projects are now more the rule than the exception and much progress has been made, large numbers of key issues remain unresolved. Prominent among these is the characterization and understanding of the various food webs and the influence on them of anthropogenic interventions (i.e. fishing and pollution) in relation to the planktonic and benthic ecosystems which are the fundamental basis of overall productivity of the oceanic biota. The importance of this information to overall fisheries success is emphasized also in the subsequent essays in this series.

The essay leaves the reader with three major questions for the future drawn from a major oceanographic report: 
1) What controls the time-varying biogeochemical state of the ocean and how will it respond to global change?

2) How will the marine food webs respond to and force global change?

3) How does carbon accumulation in the ocean as well as the release of carbon dioxide and methane respond to global change?

These key questions raise issues that in addition to those already enunciated include the following:

- What are the roles of physical and chemical drivers in determining marine food web structures and functioning?

- What are the relations among biodiversity, structure, function and stability of marine ecosystems?

- How do variations in marine food webs manifest themselves over various time and space scales?

- What is the effect of climate variability on the ocean's biological pump(i.e. carbon sequestration in the deep ocean mediated by ocean biota)?

Finally it should be noted that biological oceanography is rapidly evolving through the advent and exploitation of new technologies on the macro-scale (e.g. satellite remote-sensing) and micro-scale (e.g. genomics). It is apparent that this application of molecular tools, in particular, is fostering the development and adoption of a new field in biological oceanography i.e. microbial oceanography.

\section{History of Marine Fisheries Science}

Fisheries science is defined as biological research on factors controlling the production of aquatic species of possible or established commercial importance and estimation of their yield potential. The key role of science is to define the biological bounds within which the social and economic benefits of fishing can be pursued.

Although the roots of fisheries science in Canada date back to 1898, it was not until after the Second World War that significant efforts concerned with rational exploitation of the fish stocks were made. As a consequence, the main focus of this paper is placed on post 1950 events and the important demersal (goundfish) fisheries of that period: Atlantic cod, haddock, redfish and flatfish.

The introduction of the factory-equipped freezer stern trawler in 1954 revolutionized the fishery in the Northwest Atlantic and around the world. This type of vessel combined the more efficient stern trawling with on-board filleting machinery and frozen storage. This removed the constraint placed on distant-water fishing that had limited the trip periods to the 7-9 days that fish could be preserved on ice. Other technological improvements opened the way for diversified high volume fisheries and a consequent doubling of Northwest Atlantic catches in the 1960s. 
By the early 1970 s these increased extractions resulted in a virtual collapse of the demersal fishery and a crisis in the Canadian fisheries. The Canadian fisheries were salvaged by a combination of two events. The first was the direct financial intervention in the industry by the Canadian Government. The second was that discussions at the Third United Nations Conference on the Law of the Sea had reached a stage whereby nations felt they were in a position to declare 200 nautical mile fisheries zones. Thus Canada extended its jurisdiction over most of the fishing banks off its coast in 1977. Some important fishing areas, however, e.g. the nose and tail of the Grand Banks and Flemish Cap lay outside the new limits and required continued arrangements for international fisheries management. A new international convention came into effect in 1979 and the Northwest Atlantic Fisheries Organization (NAFO) was formed to meet this need.

With the extension of jurisdiction, Canada adopted an objective of "best use" defined in terms of net social benefits to be achieved by direct national control of the fisheries guided by annual management plans prepared with scientific advice derived from fisheries assessments and evaluations. These actions plus the earlier experiences with the NAFO predecessor, the International Commission on Northwest Atlantic Fisheries (ICNAF), led to a formalized and sophisticated fisheries data collection and assessment system to support the preparation of the annual management plan.

Ironically, despite the institution of an elaborate and comprehensive fisheries management system based upon annual scientific advice, the composition of the Canadian Atlantic landings was altered materially. What had been an east coast fishery sustained by demersal fish (mainly Atlantic cod) forming approximately $80 \%$ of the landings in the 1950 s had by the 1990s become fisheries in which invertebrates (lobster, scallop, shrimp, crabs etc.) formed more than $50 \%$ of the landings and a substantially higher percentage of the value. Specifically, the reason for this major alteration in landings was the collapse of many of the demersal stocks, particularly in the northern areas.

As would be expected with this dramatic and relatively abrupt major dislocation in the extensive fisheries of Atlantic Canada came demands for explanations as to how such a transformation could have happened. Unfortunately for such a complex event, no clear single, simple answer could be produced. Even today, there are still many unanswered questions and continuing debates with arguments descending into recriminations and accusations of all kinds, about the respective roles of fisheries and environmental change. In this essay the authors have laid out in a balanced manner a clear exposition of the sequence of events that led to this catastrophe. The examination includes frank evaluations of assumptions, conclusions drawn from these, acknowledgement of mistakes made and shortcomings in fisheries science, fisheries management and the fisheries with a candid analysis of the factual data upon which the various arguments are based. Sadly, as the collapse of major fisheries around the world clearly shows, applications of identical and/or similar approaches did not avoid equally disastrous results elsewhere. 
The conclusions drawn from the prolonged controversy over the collapse of the groundfish stocks "emphasizes the need for a return to a broader based fisheries science that puts fish stocks in the context of their ecosystem" (Halliday \& Fanning 2006). As a constructive way forward the authors suggest altered approaches and inclusion of additional institutional arrangements, including an operations research function, that they believe are essential to achieve success in fisheries management.

\section{Marine Ecosystem Assessment}

In this final essay, the initial and guiding premise is, "The collapse of major fish stocks around the world and their failure to recover even after the cessation of fishing and the perceived deficiencies in single species fisheries management has resulted in an intensified interest in the study of whole systems". Using more than 60 data series dating back to 1970 and beyond, an integrated analysis of biotic, abiotic and human variables was conducted and produced an assessment of the current state of the ecosystem of the Eastern Scotian Shelf relative to its past.

Profound changes in community composition and size distribution over the approximately 30-year period were noted. The major ecosystem changes were examined in light of important changes in the area's ocean climate. The consequences recorded show a dramatic change over the past decade with small-bodied species such as sand lance, capelin and herring becoming prominent. The most notable changes observed were shorter generation times, increased mortality levels, increased population variability and decreased bioenergetic efficiencies. Importantly, it was also discovered that the natural mortality levels for cod and haddock are 2-5 times higher than previously assumed.

Taken as a body the study is revolutionary in concept and in results. Read in conjunction with the previous essay on the History of Fisheries Science it reveals a hitherto unsuspected dynamism in the interaction of various species with each other and their fluctuating physical environment. Only through in-depth integrated analyses can such an essential understanding of the aquatic populations be gained. As the benefits for fisheries management of such a comprehensive and searching analysis of substantial ocean areas are obvious, the ecosystem approach to assessment is now being advocated generally. There are, however, also many warning voices being raised that echo the recommendations made in the previous essay on the History of Fisheries Science.

This warning is that no matter how clear the picture of the resources becomes, unless these assessments are accompanied by sound governance, ecosystem assessment will be no more effective than the systems of the past in ensuring sustainable management of fisheries. The suggestion made previously that fisheries science should be paralleled by operations research is not only good, but also probably an essential underpinning for sound fisheries management. 


\section{EDITORIAL COMMENT}

\section{Microbial concerns}

In the essay on biological oceanography the intricacies of the "microbial loop" have been touched upon in an examination of the elements of primary productivity. The microbial loop is the process whereby microbial mineralizers and their grazers reprocess and return to the food web, phytoplankton and other materials that had escaped initially; these amounts can equal approximately half of the primary production in the oceans. The importance of the microbial world in the overall biological oceanographic or biogeochemical world can be gauged by the fact that up to $97-98 \%$ of the living carbon in the seas is estimated to be composed of the bacterioplankton (bacteria and phytoplankton) and the zooplankton with the remaining 2-3\% made up of macrobiota (invertebrates, vertebrates and macroalgae) (Table 1, Fig 2) (Kepkay 2000). Thus the major question of what are the relations between elemental cycling

Table 1 Standing stock of phytoplankton biomass in the world's ocean compared with primary production and decomposition of the primary production by respiration (from Kepkay 2000)

\begin{tabular}{|c|c|c|}
\hline $\begin{array}{l}\text { Primary (phytoplankton) } \\
\text { production }^{\text {a (Gt C year-1) }}\end{array}$ & $\begin{array}{c}\text { Carbon turnover by } \\
\text { respiration (days) }\end{array}$ & $\begin{array}{c}\text { Standing stock of } \\
\text { phytoplankton }{ }^{\mathrm{b}} \text { (Gt C) }\end{array}$ \\
\hline 45 & $10^{c}$ & 1.2 \\
\hline 50 & $80^{d}$ & 11.0 \\
\hline
\end{tabular}

\footnotetext{
a Upper and lower limits of primary production from Longhurst et al. (1995)

${ }^{b}$ Calculated as the product of primary production and carbon turnover

c Lower limit of (fastest) carbon turnover from Eppley et al. (1977)

d Upper limit of (slowest) carbon turnover from Brenner (1998)
}

and food web structure is largely related to understanding the microbial activities within the oceans as these are key factors governing the dynamics of biological productivity directly comparable to the fundamental knowledge of soil microbiology and soil chemistry upon which so much of the success of modern agriculture and forestry depends. Gaining a clear picture of the microbial activities, however, constitutes a major challenge and requires considerable changes in perspective as the solution requires work in two areas of emerging importance: 1) the Archaebacteria and 2) the increasing recognition of the existence of and the major roles of biofilms.

A significant portion of the cycling of materials in the oceans is carried out by a group of microorganisms little studied in the past, the Archaebacteria. This group of prokaryotes lives in the most extreme of environments and includes hyperthermophiles, psychrophiles, methanogens, thermoacidophiles and halophiles (Grabowski \& Kelman 2003) and in fact form a domain separate from the true bacteria to which they are only distantly related. Because their culture has proved so challenging, the study of the Archaebacteria will probably have to rely largely on important additions and extensions to the genomic approach mentioned earlier. 


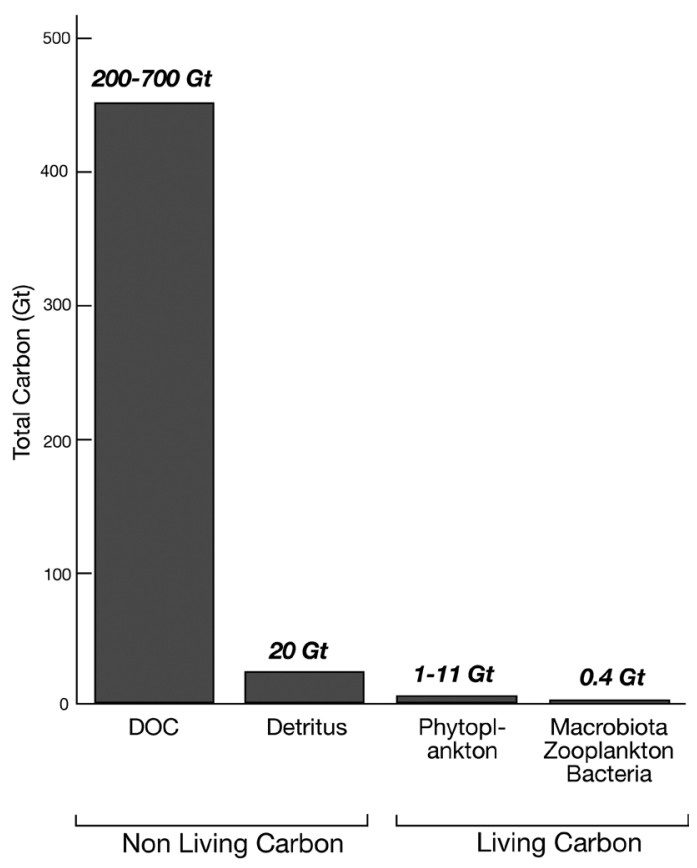

Fig 2 Oceanic living carbon vs. total carbon in gigatonnes (Gt) (redrawn from Fig 1, Kepkay 2000).

To the difficulties of dealing with the Archaebacteria will be added the problems of fathoming the activities carried out by bacteria in biofilms. It is now increasingly apparent that the bulk of the microorganisms in the water bodies do not exist or function in single planktonic forms, but actually coalesce and function in biofilms in manners quite different from the several to numerous individual species of which they are composed. Biofilms composed of both true bacteria and Archaebacteria can be thought of as multicellular organisms in which the individual members, with frequent changes in composition and basic capacities, develop new and interdependent specialities and form complex chemical signalling systems that coordinate and control responses throughout the biofilm (Shapiro 1998, O'Toole et al. 2000). Costerton et al. (1999) have defined the bacterial biofilm as a structural community of bacterial cells enclosed in a self produced matrix and adherent to an inert or living surface i.e. a protected and specialized mode of growth that allows survival in a hostile environment. An example of the complex techniques required to decipher the activities of biofilms is offered by Ram et al. (2005). They used genomic and mass spectrometry-based proteomics methods to evaluate gene expression, identify key activities and the partitioning of metabolic functions in a natural acid mine drainage biofilm community. They also found that the bacterial proteins involved in protein re-folding (stress proteins or molecular chaperones) in 
oxidative stress were highly expressed, suggesting further opportunities to use these techniques in gauging pollution effects upon biofilms and, by extension, to the effects pollution has on the food webs.

\section{Resource concerns}

Although the Eastern Scotian Shelf analysis for the NAFO Division 4VW (Marine Ecosystems Assessment) is extremely impressive, it does not answer all questions nor does it immediately exhibit the means whereby this relatively large area could or should be managed sustainably. A good example of the complexity of these issues and the challenges to science and management is revealed by examination of the long-term picture of the landings for all of Atlantic Canada of the species now generally the most valuable, the lobster, Homarus americanus (Fig 3 ). The fishery has

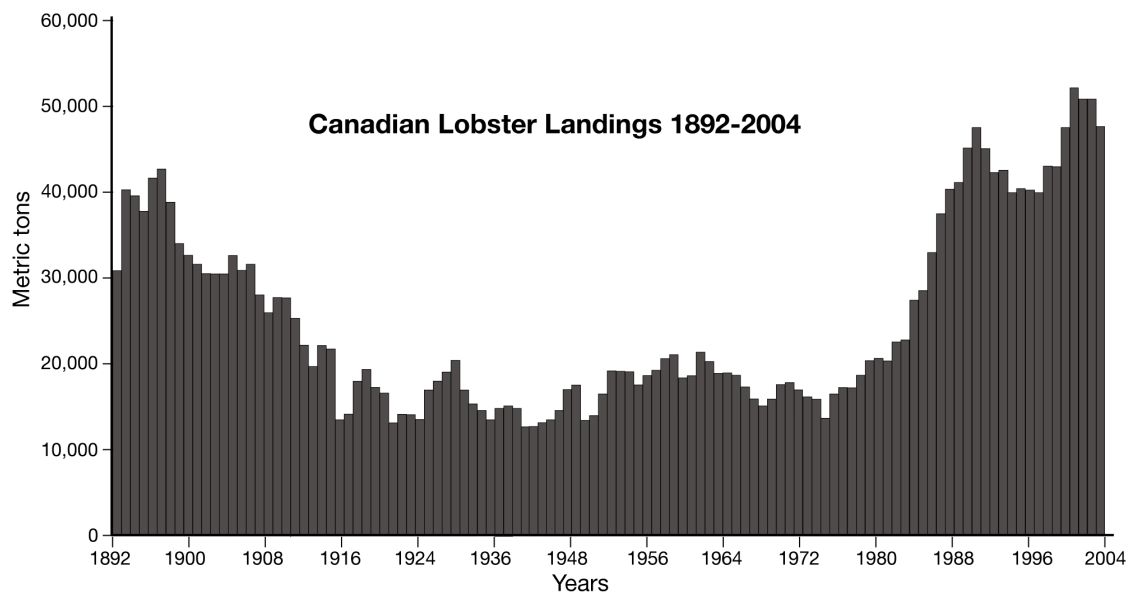

Fig 3 Canadian lobster landings 1892-2004 includes the landings in all of the areas now within the Canadian Atlantic Zone (courtesy of DS Pezzack).

existed in Atlantic Canada since the 1860 s reaching a peak in the 1880 s (McLeese \& Wilder 1964) and has been managed largely by carapace size limits, protection of the females with externally attached eggs and by limitation of seasonal access. Largely through extensive and intensive laboratory-based studies on individual lobsters, the life history, needs, behaviour and susceptibilities of the species are well understood. Unfortunately, as lobsters are solitary animals they spend much of their time on the sea bottom hidden in crevices and shelters chosen to match the animal's particular life stage. Thus, despite much study, very little quantitative information is available regarding numbers of bottom dwelling lobsters until they reach the recruitment sizes and are landed in the fisheries. On a more positive note, the New England lobster settlement index survey, recently supplemented by limited Canadian involvement, has been examining the question of variability in larval settlement. The results have been interesting and it is 
hoped that the settlement index will have predictive value for trends in the abundance of lobsters entering the fishery. As the authors state, however, the key question remains: what drives variability in lobster larval settlement in the first place (http://www.bigelow.org/srs/lobsterset.html)?

The pre-recruitment stage, in the warmer southern Gulf of St Lawrence areas is about 6 years while in the colder areas elsewhere it will run around 10 years. It is generally accepted that, in the areas fished, about $80 \%$ of the animals are captured in the year of their recruitment to the fisheries. Sexual maturity of female lobsters varies widely; in the Bay of Fundy and off southern Nova Scotia only $0-2 \%$ are mature at the minimum legal carapace size; off southern Newfoundland and in much of the southern Gulf of St Laurence $55-65 \%$ are able to reproduce at sizes below the legal size limit, while in the northern Gulf of St Laurence sexual maturity varies between 10 and $15 \%$ at the minimum legal carapace size (Pezzack 2006, see also Comeau 2003, Waddy \& Aiken 2005). Thus, the rather slender apparent reproductive capacity of the various lobster stocks is always of major concern. In addition, as the larvae upon hatching are pelagic for periods up to 45 days prior to settlement and adoption of their subsequent benthic life, it is only rarely known with certainty where the brood stock for any particular area is located and thus the apparent health and success of the brood stock upon which the area fishery depends. Although there is qualitative information on who eats whom, very little area-wide quantitative knowledge of the lobster's interaction with other species is available.

An examination of Fig 3 illustrates that the yield from this fishery has varied widely over the 113 years illustrated. As with other new fisheries, the catch consisted originally of many larger animals drawn from a relatively numerous population. As the fishery proceeded the catch levelled out to consist mainly of animals freshly recruited (Herrick 1909). But, in contrast to many continuously fished species, in about 1980 the fishery suddenly ballooned with increasing annual landings eventually reaching levels in the 1989-2004 period higher than any recorded for the fisheries previously. As the landings consist mainly of animals that are 6-10 years old at the recruitment stage, whatever accounted for this sudden increase presumably must have begun in the 1970s or even earlier and would appear to have been maintained through to at least the late 1990s.

Although an upsurge in the landings of a valuable species is commercially rewarding, enormous unexplained swings in the numbers of any stock are, of course, extremely troubling for the scientists, managers and fishers. The negative side is the possibility that an unexpected and sudden decline could also occur and be just as surprising to all concerned as was the upsurge. While it is possible to examine these data using certain of the conclusions derived from the ecosystem analyses, any such analysis will suffer the shortcomings of any proxy analysis i.e., a distinct lack of certainty as to cause. Without sure knowledge of why the surge took place originally, it is not possible to predict whether it will last or for how long and thus it constitutes a major conundrum and challenge for science, management and 
the fisheries. It also underscores the complexity of the issues that led Alan Longhurst to entitle his 2002 address to the International Council for the Exploration of the Sea "Fish stock management is an unsolved ecological problem".

\section{CONCLUDING REMARKS}

Unfortunately, although arranged to provide a sound basis for discussions concerning programs for the future, the coverage in this series of essays is not complete as it does not include such major areas as environmental science studies, aquaculture, chemical oceanography, in-depth treatment of biodiversity and most importantly discussion of more comprehensive treatment of invertebrates, macroalgae and benthic productivity generally. It is hoped that these areas can be covered in future essays as authors interested in preparing such treatises are found and/or persuaded to contribute them in the interests of programming, promotion of scientific literacy concerning the oceans and the intricacies and ramifications of ocean policies.

Acknowledgements. I thank all those who participated in the preparation of this written symposium and in particular PE Kepkay, RF Macnab and DS Pezzack who supplied the illustrations that appear in this introduction.

\section{REFERENCES}

Benner RH (1998) Cycling of dissolved organic matter in the ocean. In: Hessen DO, Tranvik LJ (eds) Aquatic humic substances: ecology and biogeochemistry. Springer-Verlag, Berlin, p 317-332

Comeau M (ed) (2003) Workshop on lobster (Homarus americanus and H. gammarus) reference points for fishery management held in Tracadie-Sheila, New Brunswick, 8-10 September 2003: abstracts and proceedings. Can Tech Rep Fish Aquat Sci 2506

Costerton JW, Stewart PS, Greenberg EP (1999) Bacterial biofilms: a common cause of persistent infections. Science 284:1318-1322

Eppley RW, Harrison WG, Chisholm SW, Stewart E (1977) Particulate organic matter in surface waters off Southern California and its relationship to phytoplankton. J Mar Res 35:671-696

Grabowski B, Kelman Z (2003) Archaeal DNA replication: eukaryal proteins in a bacterial context. Annu Rev Microbiol 57:487-516

Halliday RG, Fanning LP (2006) A history of marine fisheries science in Atlantic Canada and its role in the management of fisheries. Proc NS Inst Sci 43: 159183

Herbert GJ (1999) Canada's oceans dimension: a factbook. The Niobe Papers, Vol 11. Maritime Affairs, The Naval Officer's Association of Canada, Halifax, NS

Herrick FH (1909) Natural history of the American lobster. Bull US Bur Fish 29:149408 
Kepkay PE (2000) Colloids and the ocean carbon cycle. In: Wangersky P (ed) The handbook of environmental chemistry, Vol 5D. Marine chemistry. Springer-Verlag, Berlin/Heidelberg, p 35-56

Longhurst A (2002) Fish stock management is an unsolved ecological problem. ICES Invited Lecture, 2002. ICES Council Meeting Documents, Copenhagen

Longhurst AL, Sathyendranath S, Platt T, Caverhill C (1995) An estimate of global primary production in the ocean from satellite radiometer data. J Plankton Res 17:1245-1271

Macnab R (ed) (1994) Canada and Article 76 of the Law of the Sea. Geological Survey of Canada, Open File 3209

McLeese DW, Wilder DG (1964) Lobster storage and shipment. Fish Res Bd Can Bull 147

O'Toole G, Kaplan HB, Kolter R (2000) Biofilm formation as microbial development. Annu Rev Microbiol 54:49-79

Parsons TR (1975) Biological oceanography in Canada; a perspective and review. J Fish Res Bd Can 32: 2231-2283

Pezzack DS (2006) (Population Ecology Division, Science Branch, Department of Fisheries \& Oceans, Bedford Institute of Oceanography, Dartmouth) Personal communication

Ram RJ, VerBerkmoes NC, Thelen MP, Tyson GW and 5 others (2005) Community proteomics of a natural microbial biofilm. Science 308:1915-1920

Shapiro JA (1998) Thinking about bacterial populations as multicellular organisms. Annu Rev Microbiol 52:81-104

Sverdrup HU (1955) The place of physical oceanography in oceanic research. J Mar Res 14: 287-294

United States Commission on Ocean Policy (2004) An ocean blueprint for the 21st century: final report. Washington, DC

Waddy SL, Aiken DE (2005) Impact of invalid biological assumptions and misapplication of maturity criteria on size-at-maturity estimates for American lobster. Trans Amer Fish Soc 134:1075-1090 